\title{
Carl Warncke: De kirkelige forhold i Ullerup sogn under Besættelsen 1940-45
}

\author{
af HeNRIK SKov KRISTENSEN
}

\section{Indledning}

I antologien Den Nordslesvigske Kirke (1948) omtaler daværende sognepræst i Ullerup, Carl Warncke, over ganske få linier sine sammenstød i 1930erne og 40erne med dels de danske nazister, dels det tyske mindretal. ${ }^{1}$ I en skriftlig beretning fra 1947 med titlen De kirkelige Forhold $i$ Ullerup Sogn under Besættelsen 1940-45, som bringes nedenfor, gør Warncke anderledes detaljeret rede for disse modsætninger - så detaljeret, at pastoren fandt det betimeligt at henlægge beretningen i præstegårdsarkivet og båndlægge den i 50 år.

Warncke, som tiltrådte $i$ embedet i Ullerup i december 1933, var født sønderjyde, hvilket uden tvivl har præget hans nationale engagement. I det lille husmandshjem i Arnitlund, hvor Carl Warncke voksede op, var der 9 børn. Da han var i konfirmationsalderen, døde moderen, hvorefter moderens søster tog sig meget af børnene. Hun tog dem med til møder og lærte dem at synge efter Indre Missions sangbog.

Carl Warncke kom i tømrerlære og deltog indtil 1917 i 1 . Verdenskrig. Han ernærede sig herefter $i$ en årrække som tømrer, men fik lyst til at læse. Som 28-årig gift mand blev han student og 4 år senere teologisk kandidat. Efter 5 års præstegerning på Mors i Nordvestjylland kom han til Ullerup, som nævnt i december 1933. Her virkede han indtil sin død 27 år senere.

Straks ved sin tiltræden i Ullerup bragte Warncke sig i et modsætningsforhold til det lokale, numerisk beskedne, tyske mindretal. Ved folkeafstemningen i 1920 stemte $91 \%$ i sognet dansk og $9 \%$ tysk. Medregnes stemmerne fra tilrejste personer ikke, var tallene endnu mere i dansk favør, nemlig $96 \%$ danske mod $4 \%$ tyske stemmer. Den tyske stemmeprocent svarede til 47 fast bosiddende personer i sognet. 
Også det store antal sognebørn, som sluttede sig til det danske nazist-parti, DNSAP, kom Warncke på kant med. Det var netop under landbrugskrisens svære år, at Warncke blev sognepræst $\mathrm{i}$ Ullerup - et sogn, hvor der var forholdsvis mange mellemstore landbrug, som ramtes særligt hårdt af den økonomiske krise. Krisen gav nazisterne medvind. Dertil kom, at DNSAP's fører, Frits Clausen, i 1924 havde nedsat sig som læge i nabosognet i Bovrup, hvor han hurtigt blev en meget afholdt og søgt læge. Også mange familier i Ullerup brugte Frits Clausen som huslæge. Clausen blev hurtigt kendt som en jovial, fremkommelig og forstående mand - han sagde heller aldrig nej, når han blev budt på »en lille en«. Et vidnesbyrd om Frits Clausens popularitet i Ullerup sogn er, at han i 1932 havde holdt båltalen ved Ullerup Idrætsforenings Skt. Hansfest. Ved Folketingsvalget i 1935 fik DNSAP 168 stemmer ud af 864 i Ullerup sogn, svarende til ikke mindre end 19,5\% af samtlige afgivne stemmer. DNSAP blev derved det næststørste parti i sognet, kun overgået af Socialdemokraterne. Ved Folketingsvalget i 1939 fik partiet 154 stemmer ud af 1002 afgivne. Det tyske mindretals parti, Slesvigsk Parti, opnåede 39 stemmer i 1935 og 76 stemmer i 1939.2

Besættelsen lagde, som det vil fremgå af beretningen, ingen dæmper på Carl Warncke $\mathrm{i}$ forholdet til det tyske mindretal og de danske nazister. Ret beset er titlen på hans beretning en anelse misvisende. For nok så meget som at skildre de stedlige kirkelige forhold synes beretningens hovedanliggende at være at skildre (mis)forholdet til de personer og grupperinger, som Warncke anså for fjender ud fra såvel en teologisk som en national betragtning. ${ }^{3}$

Om redaktionen af beretningen nedenfor blot dette: den er bragt uforkortet og uændret, ligesom Warnckes gamle retskrivning er bibeholdt. Udgiveren har dog $i$ et par enkelte tilfælde valgt at anonymisere lokale aktører. Hvor udgiveren har følt det påkrævet, er beretningen blevet forsynet med opklarende noter og rubrikoverskrifter.

\section{De kirkelige Forhold i Ullerup Sogn under Besættelsen 1940-45}

Vilkaarene for det kirkelige Liv og Arbejde, mens Tyskerne var Herrer i Landet fra 1940 til 1945, var vel i Hovedsagen de samme alle Vegne og er vel kendte fra anden Side.

Som Baggrund for de Begivenheder, der førte til, at undertegnede 
Carl Warncke (1895-1960), sognepræst $i$ Ullerup 1933-60. Foto omkring 1950 i Sundeved lokalhistoriske arkiv.

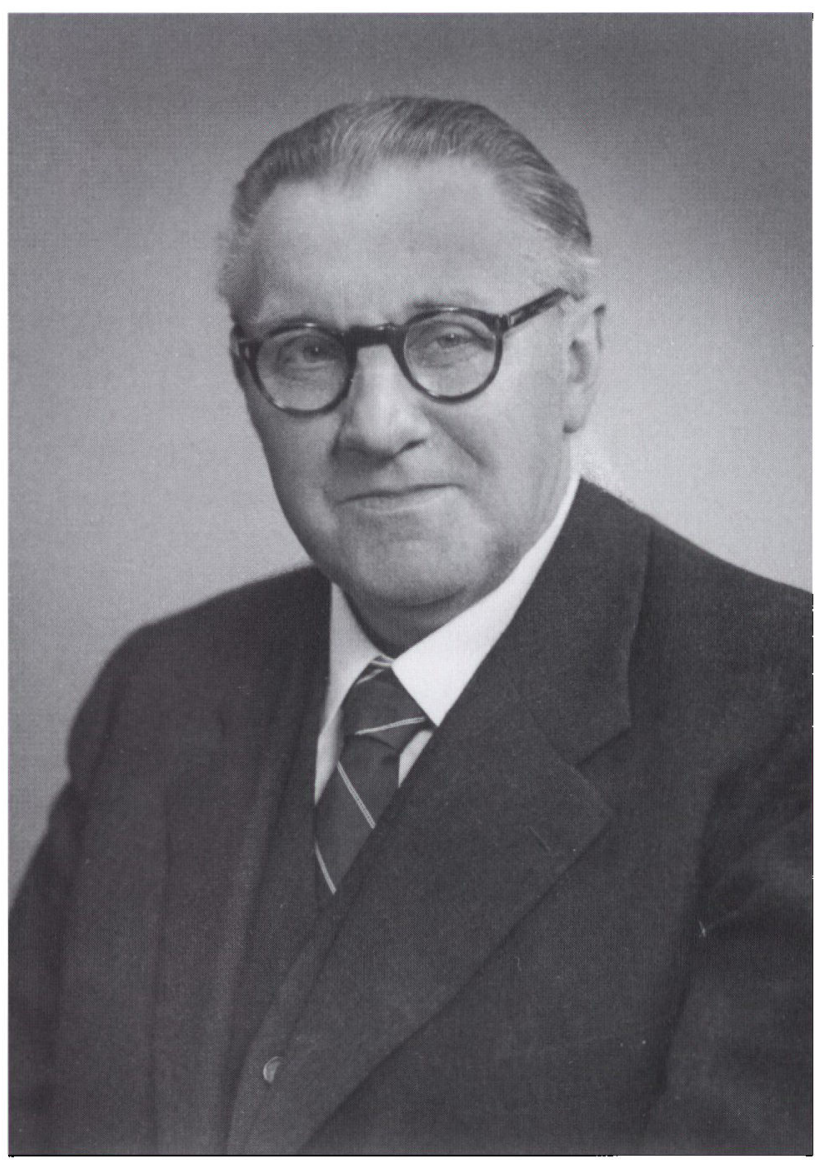

i 1944 maatte "gaa under Jorden ", være her kort anført følgende: Jeg tiltraadte Embedet som Præst her med min Indsættelse i Ullerup Kirke Søndag den 21. Januar 1934. Det var netop paa det Tidspunkt, da Nazismen i Tyskland brød igennem som den Syndflod, der vilde overskylle hele Verden, da man Syd for Grænsen truende sagde: „Vi vil indtage hele Nordslesvig og besætte det med Lynets Hurtighed «.

Ullerup var fra gammel Tid, saaledes som det ogsaa viste sig ved Afstemningen [i 1920], i national Henseende næsten rent dansk. Blev Kirkebøgerne end ført paa tysk, og forsøgte Pastor Jebsen de sidste Aar før Verdenskrigen end med ubetydelig Tilslutning at indføre tysk Konfirmation, saa foregik dog Gudstjenesterne og Menighedslivet saa at sige udelukkende paa dansk. 
$\mathrm{Nu}$ fik Nazismen imidlertid en ret stærk Udbredelse i Sognet og var med til at berede det kirkelige Liv store Vanskeligheder. Indtil Kapitulationen var dette Parti [DNSAP] repræsenteret med et Medlem i Menighedsraadet. Den faatallige hjemmetyske Kreds fik ogsaa Vind i Sejlene og rejste Hovedet med store Fremtidsplaner.

Faa Dage efter min Tiltrædelse sad Lederen [af de lokale hjemmetyskere], Grdjr. Chr. Lei, Ullerup i min Stue og forlangte Kirken overladt til regelmæssige Gudstjenester paa tysk. Ubekendt med de faktiske Forhold paa Stedet i sproglig Henseende tilbød jeg da, at jeg meget gerne vilde prædike paa tysk en Gang om Maaneden, saafremt der fandtes en Del Beboere i Sognet, som maatte ønske det og ikke godt kunde forstaa dansk. Dette Tilbud blev dog afslaaet med den Begrundelse, at det ikke saa meget var Sproget som Aanden, det kom an paa. Man vilde have en Mand, som »staar paa vor Side«. Man fik saa paa Grundlag af de sædvanlige Bestemmelser om Kirkens Brug regelmæssigt overladt Kirken til ca. 10 tyske Gudstjenester om Aaret indtil Kapitulationen. De blev afholdt af Frimenighedspræsterne Wassner, Riese og senest Horstmann, Graasten. Tilslutningen, som maatte rekvireres fra flere omliggende Sogne, var altid meget ringe, ofte under 10 Deltagere.

\section{En episode i Ullerup kirke, marts 1934}

Var Kødet saaledes kun skrøbeligt, saa var Aanden - i al Fald hos "Førerne« - sikkert villig nok, hvad følgende Episode turde være Bevis paa. Vistnok Tirsdag den 20. Marts 1934 kom 2 af Menighedsraadets mangeaarige Medlemmer og Danskhedens gamle Forkæmpere Grdjr. Andr. Madsen og Peter Beck oprevne ind i Præstegaarden og udbrød: "Nej, Pastor Warncke, nu gaar det ikke længere, nu bliver Tyskerne dog for uforskammede. Har De hørt, hvordan de opførte sig i Kirken i Søndags? « De fortalte mig det forefaldne, og vi blev enige om at telefonere til Biskop Valdemar Ammundsen i Haderslev for at bede ham om en mundtlig Samtale om Sagen. Denne blev aftalt til Mandag den 26. Marts. Hvad det drejede sig om, fremgaar af følgende Uddrag af den skriftlige Indberetning, som Biskoppen udbad sig tilsendt forinden:

"I Forbindelse med Gudstjenesten i Søndags Eftermiddag Kl. 2 (den 18. Marts, forbundet med Konfirmation af 3 udensogns Børn) optraadte Hr. Wassner (tysk Frimenighedspræst) og en Del af Deltagerne paa en saadan Maade, at 
Menighedsraadet ikke mener at kunne lade det gaa upaatalt hen, idet baade Loven og Grænsen for Sømmelighed utvivlsomt er bleven langt overskredet. Hr. Wassner synes selv at have foranlediget Tilslutning til Gudstjenesten fra bestemt Sognet uvedkommende Side. Kl. 2 kom en Flok paa 15-20 unge Mennesker, Studenter fra Hamborg, $i$ sluttet Trop, $i$ Uniformsdragter med Tornystre, lange Støvler, Musikinstrumenter, forskellige Stænger og Redskaber marcherende op imod Kirkeindgangen. Der havde Hr. Wassner taget Opstilling $i$ Ornat og hilste Flokken med den tyske Hitlerhilsen, oprakt hojre Arm. Ugenert slog Flokken med hele Udstyret sig ned $i$ Kirkens Stolestader.

Det mest forbavsende og forargelige var maaske endda, at da Kirkebetjent Johan Petersens Døtre var i Færd med at ringe Kirkens Klokker (saaledes som de ofte plejer at assistere deres Fader) kommanderede Hr. Wassner med Ordene "Jetzt wird geläutet! « to af de uniformerede Mænd op $i$ Klokketaarnet, hvor de brutalt rev Klokkerebene ud af Haanden paa de unge Piger og selv ringede videre. Imidlertid var de ikke $i$ Stand til at faa Klokkerne standsede igen, hoorfor de maatte kalde Kirkebetjenten til Hjælp.«

Sagen, som i alt væsentligt forholdt sig som anført - Pastor Wassner hævdede dog, at de unge Fyre uden hans Viden og Vilje var trængt op i Taarnet - vakte betydelig Opsigt, blev udførligt behandlet i Bladene, bl.a. en afsluttende Redegørelse af Pastor Warncke i Hejmdal for 31.3.1934, og endte med en advarende Skrivelse fra Biskoppen til den tyske Præst, ledsaget af en Cirkulæreskrivelse til Ledelsen af de tyske Frimenigheder, hvori alvorligt fremhævedes Betingelserne for Frimenighedernes fortsatte Brug af Kirkerne.

\section{I konflikt med de danske nazister, marts 1936}

Grænsen mellem [hjemme]Tyskerne og de danske Nazister blev i de Aar meget udflydende og de optraadte som Regel også som Aandsfrænder. Efter Gudstjenesten en Søndag i Marts 1936 blev en nazistisk Gaardmand som Repræsentant for "Partiet« tilbage ved Kirkedøren for at invitere mig til et "Partimøde« hos Gæstgiver Sibbesen i Ullerup Fredag den 27. Marts, hvor »Føreren« Frits Clausen selv vilde have en Meningsudveksling med den forholdsvis nye Præst i Ullerup. Mødet refereredes bagefter i National Socialisten under en trespaltet Overskrift saalydende: »Marxist Præstens Opgør med sin nationalsocialistiske Menighed «. Om Anledningen til Mødet hed det desuden i det fordrejede Referat: 
"I Fredags holdt Ullerup Afdeling [af DNSAP] Medlemsmøde med indbudte Gxster og en særlig Sag paa Dagsordenen. Forholdet er nemlig dette, at Sognepræsten, Pastor Warncke, $i$ længere Tid systematisk fra Prædikestolen Søndag efter Søndag har angrebet Nationalsocialisterne paa meget illoyal Maade. Det har været aabenbart for Kirkegængerne, at Pastoren af politiske Grunde har angrebet Nationalsocialisterne uden at kende Nationalsocialismen og uden at soge at sætte sig ind $i$ dens Ideer. For at tale ud om dette havde Nationalsocialisterne indbudt Pastor Warncke til ovennæonte Medlemsmøde, hvor Pastoren havde Lov til at tage Meningsfxller med".

Skønt Mødet, der var arrangeret i den kendte bombastiske Stil med et dresseret Korps af fanatiske Klappere i lange Støvler; som brølede Bifald til Dr. Clausen, der i sin Tale fremsatte Trusler paa Livet mod navngivne Mænd, varede til $\mathrm{Kl}$. 1, kom vi ikke hinanden nærmere. Lidt senere inviterede vi Nazisterne til Præstegaarden til videre Drøftelse uden større Resultat.

Derimod havde ovennæunte Referat til Følge, at jeg foruden at blive angreben videre i Nazibladet modtog Truselsbreve bl.a. fra en Hr. Asmus Paulsen jr. i Flensborg. Følgende er Uddrag af det første fra denne, dateret den 5.4.1936:

\section{"Hr. Pastor Warncke}

Jeg har med Interesse læst om det Møde hvor De var indbudt. Jeg tilraader Dem Hr. Pastor, hold Dem uden for Politik, det sommer sig ikke for en Sjælesørger, pas Kirken, saa tjener De Gud og Deres Menighed, som er Dem betroet. Ligeledes beder jeg Dem undlade at blande Dem $i$ Forholdene her ovre. Deres Mening om Nationalsocialismens Ideer betyder intet, da jeg har forstaaet at De ikke har Evner at opfatte samme - istedetfor staar De og forfægter et System der er saa raaddent og djævelsk. Herr Pastor, jeg haaber at De vil komme til Indsigt inden det er for sent, for forst naar Kommunismen overskrider den danske Grænse i Natura, saa ved De sikkert som det er sket $i$ Rusland, at Præsterne er de første, der bliver myrdede - Hil Nationalsocialismens Forkæmper Hitler, og Hil Danmark.

Deres ærbødige A. Paulsen.«

Dette førte til en længere Brevveksling, under hvilken Hr. Paulsen sendte mig forskellige Avisudklip og Flyveblade, bl.a. ogsaa Der Stürmer [rigstysk nazistisk, stærkt antisemitisk blad]. Aandsfællesskab opnaaedes heller ikke i denne Forbindelse. Men ejendommeligt 
nok at tænke paa, at Nazismen den 9. April 1940 ret kom over den danske Grænse i "Natura", og at Kaj Munk blev myrdet den 4. Januar 1944.

\section{Kontrovers med et sognebarn, 1940}

Som Eksempel paa den Mentalitet, der straks besjælede visse Landsmænd med Tyskernes Overfald paa vort Land, anføres følgende Episode. I 1940 foretoges en Udvidelse af Kirkegaarden i Ullerup. En herboende Mand, J.N., som ofte havde haft Arbejde for Menighedsraadet og for mig privat, men dog mente, at han aldrig var kommen til sin Ret, trængte sig ind i Arbejdet paa Kirkegaarden under Anvendelse af Trusler overfor Arbejdslederen. En Dag kom han ned til mig og - som det passede sig for et Herre-Menneske - nærmest forlangte Tilladelse til at samle Brænde i min Skov. Da jeg i den Forbindelse foreholdt ham den kedelige Maade, hvorpaa han var kommen ind $i$ Kirkegaardsarbejdet, blev han helt rasende og sagde: "Naa, skal der ogsaa blandes Politik i den Sag. Tag De Dem i Agt, nu har vi faaet en anden Tid.«

Derpaa holdt han en knyttet Næve op for Hovedet af mig og raabte: "De skal komme til at pakke Deres Kuffert, det kan De stole paa!«

Han gik igennem Isen og druknede i Als Sund den 7. Februar og blev først fundet og begravet paa den udvidede Kirkegaard den 3. Maj 1947.

\section{En artikel med konsekvenser, september 1942}

Der faldt i alt i Ullerup Sogn i Krigen ca. 30 bomber, hvoraf en Del meget svære. De første faldt $i$ øvrigt saledes, at de ved at være sluppet et Sekund senere vilde være gaaet ned i Gaarden hos den mest virksomme Nazifamilie og Menighedsraadsmedlem i Avnbøl. En anden Serie faldt ca. $100 \mathrm{M}$. fra Kirken uden at anrette Skade.

Men Natten til den 19. August 1942 blev nok den værste i den Retning. Der var en hæftig Luftkamp over Egnen, som særlig kom til at ramme Ullerup Sogn og de lige overfor liggende Sogne paa Als, særlig en del af Nordborg Sogn. Alene den Nat fandt der 18 svære Bomber i den nordlige Del af Sognet foruden utallige Brandbomber, hvoraf en Mængde omkring Præstegaarden. 2 Husmandssteder brændte, mens Beboerne kun i sidste Øjeblik reddede sig fra Flam- 
merne og, som det synes, kun ved et Mirakel undgik at blive dræbt af Bomberne. Masser af Ruder blev knust og flere Ejendomme stærkt beskadigede, men intet Menneskeliv gik tabt her eller på Als-Siden. ${ }^{4}$

Mens Pastor Lænkholm i Nordborg holdt en Takkegudstjeneste for den underfulde Beskærmelse i Faren, skrev jeg om Begivenheden i Sognets Kirkeblad for September 1942, idet den dannede Baggrunden for Betragtningen: "Jeg tror paa Gud Fader den almægtige« med Teksten fra Ordsprogene 18.10: "Herrens Navn er et fast Taarn, den retfærdige løber til det og bliver beskyttet«.

Bladet blev af Sognets Hitler-Tyskere sendt som formentlig kriminelt til »højere Vedkommende«. Om Morgenen den 7. Oktober fik jeg da en truende Opringning fra Bovrup:

»De taler med Lærer Jürgensen (den berygtede Asmus von der Heide). Jeg ringer på den tyske Organisations Vegne, og det er officielt. De har i Deres Kirkeblad for September beskæftiget Dem med Krigen og bl.a. skrevet: "Hvorledes skal det gaa vore Børn? Skal Børn, der opdrages efter Kristentroens Aand og Grundsætninger kunne faa en Fremtid i Verden Side om Side med en Ungdom, der med Statsmagt opdrages til Gudløshed, krigerisk Raahed og Lovløshed? « Jeg spørger Dem, Hr. Pastor, har De ved den Ungdom, som opdrages saaledes med Statsmagt, tænkt paa den tyske Ungdom?«

Svar: "Hr. Jørgensen, De er mig jo ubekendt og jeg kan ikke vide, om De er den, De foregiver. Mit Kirkeblad er beregnet paa mit Sogn, og jeg vidste ikke, at De i Bovrup ogsaa var Holder. Hvad mine Tanker angaar, maa jeg bede Dem holde Dem til, hvad jeg har skrevet. Hvad jeg iøvrigt tænker, vil jeg ikke drøfte med Dem i Telefonen, men hvis det har Interesse for Dem, kan De træffe mig her i Præstegaarden.«

Han: »De kan og skal her med det samme svare paa, om De sigter til den tyske Ungdom, Ja eller nej.«

Jeg lagde Roret paa.

Hr. Jürgensen fremkom saa i Nordschlewigsche Zeitung for 10. Oktober med et Angreb, der blev Begyndelsen til en lang Række meget fjendlige Artikler under Rubrikken Unsere Stimme i Nordschleswigsche Zeitung. Under Overskriften.: "Ein dänischer Pastor beleidigt die deutschen Erzieher« skrev Hr. Jürgensen bl.a.:

"Wir sind der Ansicht, dass die Beleidigung unserer Jugend, die im heiligen Glauben an ihre Sendung zu Tausenden ihr Leben opfert, auch von einem 


\section{Cin sani beleidigt Die beut}

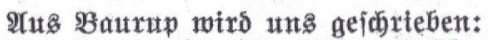

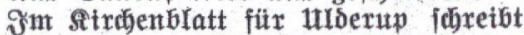

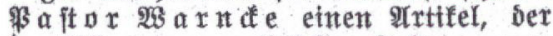
Sentlich eine politifice Spibe gegen

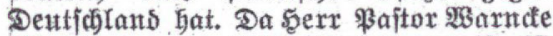
ars Begner Deutfolando befannt ift, ift ber शrtifel an fíd nicht weiter auffäl= Itg. Âtuffältg aber ijt ber faft uttglaub=

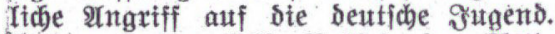
Dá̉ ex Das engltiche Bolf in dem $\mathfrak{A r t i}=$

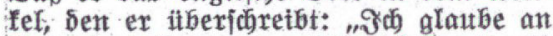

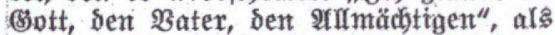

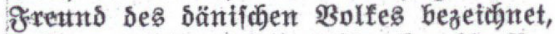
megmen wix zur Senntnib, aber bie $\mathfrak{B C}=$ leibigung unferex Jitgend fant einfach nidbt geouldet mexben. Es hetpt in bem Sak:

"2rie foll es tuieren gindert geljen?

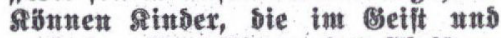
tad ben Grunbiägen bes Ebriften: glaubens exzegen wexben, cine $3 \mathrm{st}$ funft erbalten in ber Seite mit einer Jitgent, bie mit

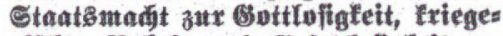

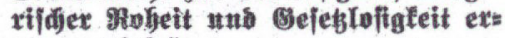
agtent wirs."

itber bie Meinung in diefem Sab fant fein Bmeifel beitehen: Die \$orte "Sette an Seite" und "mitt Staatsmadt"

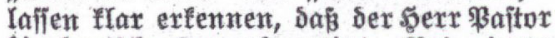

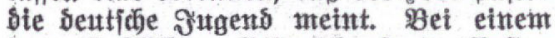
fernmïnolidben Befpräch iagte Fajtor

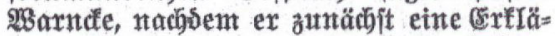
rung itberfaupt verweigert Gatte, $\mathrm{Da \beta}$ ex: bie "beutide જugens nidat "ipeziell"

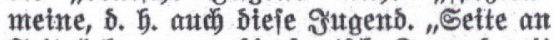
Seite" fant nur sie sentiche Jutgens mit

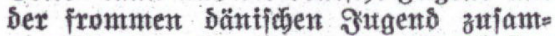
menlében - oder metnt ber serr \$aftor

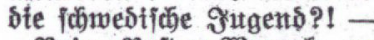

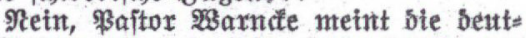
fobe Jugents - Daritber fant feit 3 wet= fel herridjent. went ex ę Yeutgtet, Dant fitgt ex nut o zu ber unglaublteben Belet= Stgung eine berwinte 1trmabrbeit - ober

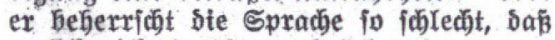

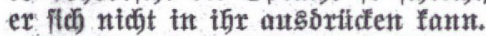

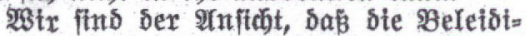
gung unferer gotgent, sie im beiligen

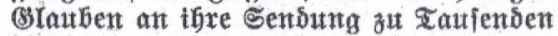
t5x Reben opfert, attíl oon einent \$aftor nidbt gesulbet werben eant, fonsernt the unverzatgliche Sithne finsent mus. §.
Boorup-læreren Asmus Wilhelm Jürgensens (Asmus von der Heide's) angreb på pastor Warncke $i$ Nordschleswigsche Zeitung 10. oktober 1942. 
Pastor nicht geduldet werden kann, sondern ihre unverzügliche Sühne finden muss.«

Nazibladet Fædrelandet var ogsaa straks med. Under Mærket "K.S.« bragte det den 26.10.42 en stort opslaaet Artikel: "Atter en Præst paa Krigsstien. Pastor Warncke fra Ullerup mener at kunne skænde den Ungdom, der kæmper og bløder paa Europas Østfront.«

Ogsaa anonyme Truselsbreve indløb:

"Til den mærkelige Præst! Nu kan Di jo selv afgøre om Di mener, det formaalstjenligt at fortsætte med Deres Hetzpropaganda. Kender Di Pastor Niemoller? ${ }^{5}$ Di ønsker maaske at gare denne Selskab?

Di kan regne med Klage til Kirkeministeren, og saa skal vi se om Di fortsat kan regne med at blive i Embedet. I det nye Danmark, som er $i$ Anmarch er Di fuldkommen overflødig, den Slags Figurer vil der ikke blive Brug for, Gud ske Lov. Prov nu at tænke, hvis Di kan tænke, om ikke Di kan se Di er paa en illegal Vej.

Dansk Front"

Hvad der videre skete, ses bl.a. af en leder i Hejmdal for 16. Febr. 1943 med Overskriften: "Dr. Møller paa Krigsstien«, hvori læstes:

"Det herværende tyske Mindretals Folketingsmand, Dyrlæge Dr. Jens Møller, Graasten, har været ude med en meget aggressiv Tale ved et tysk Partimøde $i$ Haderslev, hvori han ogsaa fremsatte en Rakke Angreb paa danske Mænd, som udmundede i en Resolution, der i telegrafisk Form blev tilstillet Stats-og Udenrigsminister Scavenius med folgende Ordlyd:

»1000 til et Møde $i$ Haderslev forsamlede Tyskere vedtog $i$ Mindretallets Navn følgende Resolution: For at værne vort Folks og de europæiske Frontkæmperes Ære og for at opretholde den hjemlige Fred kræver vi indledet Straffeforfølgelse mod Lektor Rosent, Aabenraa, Provst Schülein, Løgumkloster $^{6}$ og Pastor Warncke, Ullerup, og deres Fjernelse fra Grænselandet.

Haderslev, den 14. Febr. 1943.

sign. Dr. Moller.

Forer for Mindretallet."

Ogsaa gennem det tyske Gesandtskab blev en tilsvarende Klage sendt til Statsministeren. Sagen gik saa til Kirkeministeriet, og gennem Biskoppen fik jeg Sagens Akter tilstillet til Erklæring. Der var nu kommen 
den Beskyldning med, at jeg fra Prædikestolen fremkom med fjendtlige Udtalelser om Tyskland og den tyske Folkegruppe [det tyske mindretal]. Under 5. Marts sendte jeg Sagen tilbage med følgende Erklæring:

"Til de $i$ Henvendelsen fra det tyske Gesandtskab mod mig fremsatte Klager, at jeg, "fra Prædikestolen fremkom med fjendtlige Udtalelser om Tyskland og den tyske Folkegruppe", skal jeg herved meddele, at dette har aldrig fundet Sted. Dyrlæge Moller har aldrig været Tilhører $i$ min Kirke, og hele Paastanden er af en saadan Art, at den aldrig kan bevises ved haderlige og sandfxrdige Midler. Der findes $i$ mit Sogn slet ingen tysktalende Beboere. Mit Forhold til de meget faa tysksindede Familier kan belyses ved, at jeg ved min Embedstiltrædelse her $i$ 1934, da man forlangte Kirken til tyske Gudstjenester, tilbød selv en Gang om Maaneden at prædike paa tysk.

Artiklerne $i$ Nordschleswigsche Zeitung beskxftiger sig med en opbyggelig Betragtning $i$ mit Kirkeblad, hvor jeg beskyldes for at have fornærmet den tyske Ungdom og dens Opdragere ved at bruge Udtrykkene »Gudløshed, krigerisk Raahed og Lovløshed «.

Overfor dette maa jeg henvise til den nævnte Artikel i Kirkebladet, som vedlægges. Der findes overhovedet ingen nationale Betegnelser $i$ Forbindelse med den omtalte Ungdom. Det paaankede Citat er desuden revet ud af sin Sammenhæng, hvorved fremkommer en tilsigtet Fordrejelse af hele Artiklens Tendens. (jvf. f. Eks. Artiklens Slutning).

Skont jeg naturligvis deler mit Folks Langsel efter, at de fremmede Tropper snart vil forlade vort Land, kan Beskyldningen, at jeg er wen Fjende af det tyske Folk«, ikke opretholdes.

(Hermed vil jeg ikke have lagt Skjul paa min Overbevisning, at den nationalsocialistiske Livs- og Verdensanskuelse er $i$ afgjort Modstrid med Kristendommen som den læres $i$ Bibelen og vor Kirkes Bekendelsesskrifter. Kongen har ved sit Kaldsbrev betroet mig Præsteembedet paa de Vilkaar, som findes $i$ det højtideligt afgivne Præsteløfte, hvorved man forpligtes til »at forkynde Guds Ord rent og purt" og "bekæmpe saadanne Lardomme, som strider mod Folkekirkens Trosbekendelse". "Alt dette lover jeg med Regnskabsdagen for Øje samvittighedsfuldt at ville holde, efter den Naade, som Gud mig dertil vil forlene".

Dertil forventer jeg ogsaa underdannigst Kongens Beskyttelse og skal forøvrigt $i$ Guds Navn gaa ind under Folgerne)《.

Søndag den 14. Marts kom Biskop Noack personligt bilende herned for at faa det sidste indklamrede Afsnit erstattet med følgende: "Jeg 
har saavel $i$ Tale som $i$ Skrift bestræbt mig for, tro mod mit afgivne Præstelofte at forkynde Guds Ord rent og purt og bekæmpe saadanne Lærdomme som strider mod Folkekirkens Trosbekendelse. Og dette forventer jeg fremdeles at faa Lov til i fuld evangelisk Frihed ".

Det gik jeg, omend nødig, med til - men Biskoppen gjorde gældende, at da Sagen angik Tyskerne, var det ikke værd at drage ogsaa Nazisterne med i den. Ligeledes mente han ikke, at man paa det Tidspunkt burde hentyde til Kongemagten.

\section{For provsteretten, maj 1943}

I Skrivelse fra Biskoppen af 20. April 1943 fik jeg Meddelelse om, at Kirkeministeriet havde paalagt ham at foranledige Sagen undersøgt ved en Provsteret, og "naar Undersegelsen er afsluttet udbeder man sig Indberetning om Resultatet af denne.«

I de første Dage af Maj var jeg i København og benyttede Lejligheden til en Samtale med daværende Kirkeminister Holbøl. Ministeren, for hvem jeg præsenterede mig som en af hans gamle Studenter $i$ Kirkeret, var meget elskværdig. Paa mit Spørgsmaal, hvorledes man i Ministeriet saa paa Sagen, svarede han: "For Provst Schülein ser det maaske mere alvorligt ud, men i Deres Sag er der efter min Mening ikke mere end der kan ligge bag paa min Haand. Men Tyskerne vil have, at der skal ske noget med Dem, enten skal De skydes eller deporteres eller hænges. Forleden kom Deres Dyrlæge (Møller) hen til mig her nede paa Gaden og paa mit Spørgsmaal, hvor han agtede sig hen, svarede han ophidset: "Jeg skal op at tale med Dem om Deres Præster. De maa gøre noget for at holde Styr paa dem «.

Torsdag den 27. Maj Kl. 10.15 mødte jeg da for en Provsteret paa Domhuset i Graasten. Denne bestod af Dommeren Gredsted og Provst Rohleder, Broager. Under Forhøret var Dommeren meget elskværdig og syntes at ville opnaa et Resultat til Protokollen, som kunde fjerne alle Vanskeligheder for mig. Jeg udtalte derfor, at jeg fuldt ud stod ved alt, hvad jeg havde skrevet og $\mathrm{i}$ ingen Henseender vilde have mine Udtalelser bortforklarede eller afsvækkede. Beskyldninger for fjendtlige Udtalelser fra Prædikestolen mod det tyske Folk maatte jeg naturligvis benægte.

Noget skulde der altsaa ske, og der skete da det, at Biskoppen under 16. Juli maatte ekspedere en ministeriel »Næse« til mig. Skrivelsen begyndte saaledes: "Med Deres Højærværdigheds Skrivelse af d. 1. 
juni d.A. har Ministeriet modtaget Udskrift med tilhørende Bilag af Retsbogen for Lundtofte og Nybøl Herreder«. Denne citeres, hvorefter Slutningen lyder:

"I Anledning heraf skal man anmode Deres Højærværdighed om tjenstligt at ville paalægge Sognepræst Warncke fremtidig at afholde sig fra saadanne Udtalelser, der som de herom meldte er holdt $i$ en saadan Form, at de kan give Anledning til Misforstaaelse ikke mindst under hensyn til, at et ikke ringe Antal Frikorpsmedlemmer [Frikorps Danmark] er hjemmehørende der paa Egnen«.

Tyskerne var tilsyneladende tilfredsstillede. I Nordschleswigsche Zeitung for 30. Juli stod bl.a. under Overskriften »Das Kirchenministerium zum Fall Schülein - Warncke«:

"Das Kontor der deutschen Volksgruppe beim Staatsministerium teilt uns mit, dass das Kirchenministerium durch den zuständigen Bischof sowohl dem Probsten Schülein als auch dem Pastor Warncke einen Disziplinarentscheid übermittelt hat $-z u$ dem vorstehenden Bericht könnte noch sehr viel ausgeführt werden. Wir begnügen uns heute zunächst mit der Feststellung, dass amtlicherseits von dem Verhalten der beiden Pastoren abgerückt wird."

Som Eksempel paa den udmærkede Solidaritet, der gennem hele Krigen raadede i Præstestanden anføres følgende to smaa Breve, som jeg modtog lige efter, at Biskoppen havde sendt mig den ministerielle Tilrettevisning:

"Kære Pastor Warncke!

Som Supplement til min sidste Skrivelse kan jeg ikke dy mig for at sende Dem nedenstaaende Udklip:

\section{Alvorlig Advarsel!}

Politifuldmægtig Tønnesen: Anklagemyndigheden kan gaa med til, at de Herrer slipper med en Advarsel.

Dommeren: Hvad skal de advares mod?

Tonnesen: Fastholdt sin Paastand.

Dommeren: Hr. Thaysen, De har ikke gjort noget galt, men De maa aldrig gøre det mere! (Nordsjillands Venstreblad).

Med venlig Hilsen. Haderslev, d. 13.8.43.

Deres hengivne Noack«. 


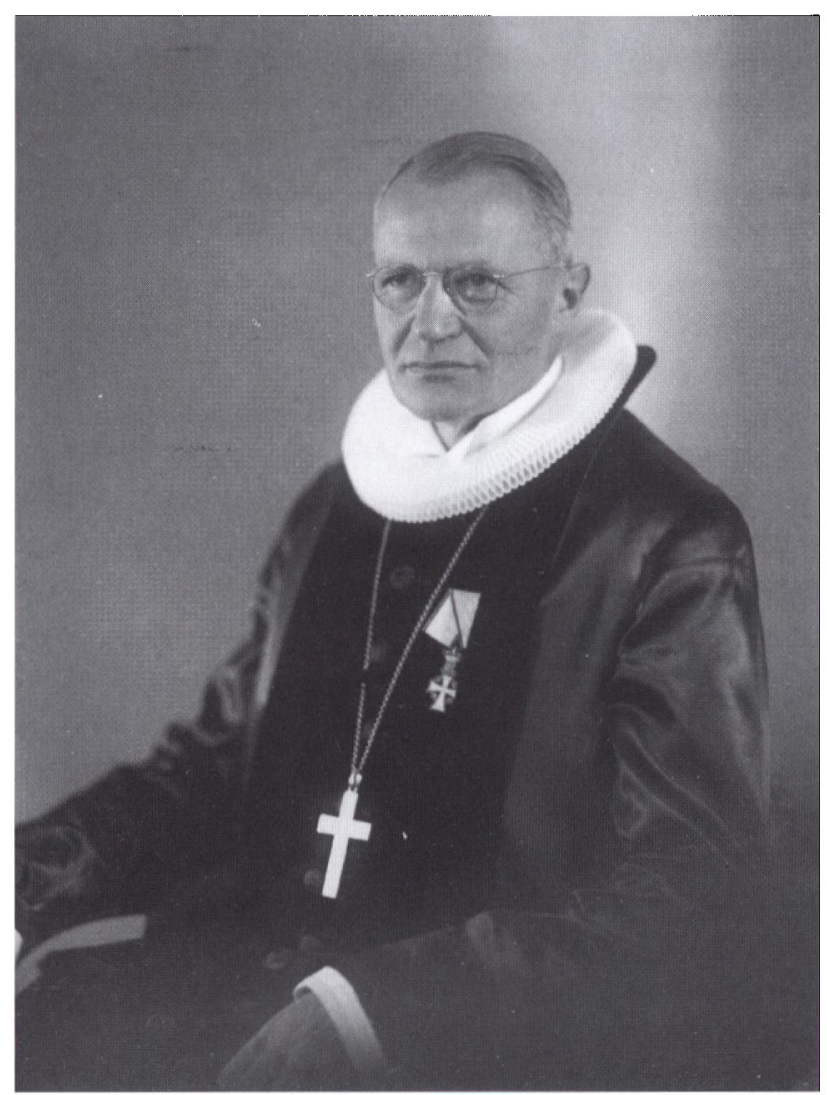

Carl W. Noack (1885-1960), biskop i Haderslev 1937-1955. Under besættelsesårenes vanskelige forhold nod Noack stor anseelse. Han var $i$ besiddelse af stor myndighed og bevarede også under krigen et godt forhold til Nordslesvigs tyske præster. Foto $i$ Institut for Sonderjysk Lokalhistorie.

»Herr pastor Warncke!

Hjertelig til lykke med den tildelte Udmærkelse, der er dog smaa Lyspunkter $i$ det meget Tusmorke.

Ø. Velling, d. 8.8.43.

Venligst Deres Aage Sletten “.

\section{Sygeorlov og britisk flyver i præstegården, 1944}

At Tyskerne under krigens Gang og Forholdenes Udvikling herhjemme havde vanskeligt ved at undgaa Nervøsitet fremgik af den store Razzia Natten til den 29. Aug. 1943, da en Mængde førende danske Mænd Landet over blev arresterede. ${ }^{7}$ Blandt dem var provst Schülein, hvem jeg intet anende havde besøgt Torsdagen forud. Han blev indsat 
paa Kasernen i Tønder, men senere løsladt igen. Snart efter kom Tyskernes Overfald paa de danske Jøder. Ved Kaj Fønss-Jørgensens Begravelse i Egen Kirke den 2. Oktober omdelte Biskop Noack til alle de tilstedeværende Præster i lukket Konvolut en Skrivelse med Paalæg om at oplæse den ved Gudstjenesterne i alle Kirker næste Dag. Det var Biskoppens og den danske Kirkes Protest mod Jødeforfølgelsen. Den blev altsaa som i hele Landet oplæst i Ullerup Kirke Søndag den 3. Oktober, idet jeg i Forvejen havde bedt alle Menighedsraadets Medlemmer om at være til Stede.

Onsdag den 5. Januar 1944 kom jeg sent hjem fra Skoven og fandt Familien i oprevet Sindstilstand. Et Par af Drengene gik paa Havegangen og ventede, kom saa løbende og sagde: »Far, Kaj Munk er bleven myrdet, det har Tyskerne gjort.« Jeg kom i Tanker om Hr. Paulsens Advarsel fra Flensborg: - "saa er Præsterne de forste, der bliver myrdede" og bemærkede til en Mand fra Sognet, som var til Stede: "Ja, der begynder at blive mindre hyggeligt, man bør maaske holde sig i Alarmberedskab og være belavet paa alle Eventualiteter«.

Siden 9. April 1940 og i Tiden derefter havde mit Hjerte begyndt at gøre Vrøvl, og det havde i flere Perioder været en ret generende Lidelse for mig. Lægen havde flere Gange foreslaaet mig at tage paa Kur for at faa fuldstændig Ro og blive grundigt undersøgt. Jeg besluttede da nu at gøre Alvor af dette og benytte den urolige Tid til en mulig Forbedring af Helbredet, hvorfor jeg blev indlagt paa Statshospitalet i Sønderborg med Syge-Orlov i 4 Måneder.

Det var i de Tider, da de engelske Flyvere Nat efter Nat i Tusindvis dundrede hen over Egnen. Da mine to største Drenge Søndag den 30. Jan. besøgte mig paa Hospitalet, havde de en spændende Historie at fortælle hjemmefra. Da den ældste, Chim, Lordag Aften kom fra Skole og skulde stille Cyklen ind, blev han forskrækket ved en mystisk puslen fra Mørket i Cykleskuret. Da han fik tændt Lys, stod en ung engelsk Flyverløjtnant for ham. Han var noget forslaaet i Ansigtet og havde forstuvet den ene Fod ved Faldet. Chim fortalte ham paa engelsk, at han var i Danmark og mellem Venner. Da han var kommen til Ro i Stuen, fortalte han, at han den foregaaende Nat sammen med sine Kammerater havde maattet springe ned med Faldskærm fra deres Bombemaskine, som var bleven ramt og styrtet ned kort efter, han var saa gaaet ind $i$ vor Have og havde siddet skjult $i$ den store Rhododendron fra Fredag Nat kl. 2 til Lørdag Aften, da han var listet ind i Laden og blev funden. Hans Navn var Ronald Pilgrim. Han 
var startet fra Kettering Flyveplads, denne gang paa sin 28. Tur over Danmark til Tyskland. Han var fra Manchester. Min Hustru ringede efter dr. Hansen, V. Sottrup, som sammen med sin Hustru straks kom til stede og forbandt ham. Efter at ogsaa Pastor Nielsen, som betjente Embedet under mit Fravær, var tilkaldt, raadslog man til langt ud paa Aftenen om, hvorledes den unge Mand kunde hjælpes til Sverrig, hvad han meget onskede. Desværre havde vi dengang endnu for ringe Kontakt med de "underjordiske" Kredse paa Sjælland til, at det kunde gennemføres. Resultatet blev derfor, at han overnattede hos dr. Hansens, hvor han (efter at en fortrolig - telefonisk - Henvendelse til Politimesteren i Graasten om Raad og mulig Hjælp var bleven afslaaet med Advarsel) maatte afleveres til tyskerne Søndag Morgen. Han kom dog godt hjem fra Fangenskab, og vi har siden opnaaet Forbindelse med ham. ${ }^{8}$

\section{Oberst Paludan-Müller og dagens tekst, pinsen 1944}

Med Søndag den 21. Maj overtog jeg igen Betjeningen af Embedet, og Fredagen derefter fandt Mordbranden Sted paa Oberst Paludan-Müller i Graasten. En Rystelse af Afsky greb alle. Da jeg om Lørdagen forberedte min Pinseprædiken til næste Dag, kom min Fætter fra Graasten og fortalte mig som Øjenvidne, hvad der var sket. Det fik uundgaaelig nogen Indflydelse paa Gudstjenesten og Begivenhedernes Gang Pinsedag. Gudstjenesten var stærkt besøgt bl.a. ogsaa af en Del af de mest haardnakkede Nazister. I Teksten hed det: "Dersom I elsker mig, da hold mine Befalinger", og "den, som har mine Befalinger og holder dem, han er den som elsker mig «. Dertil sagde jeg bl.a.:

"Dette betyder selvfolgeligt Krav til os om, at der skal være Overensstemmelse mellem vor paastaaende Kristendom og vore Gerninger og Sympatier. Man kan, for at anfore et fatteligt Eksempel, ikke være Forbryder eller sympatisere med Voldsmænd og Mordbrændere og samtidig hævde at være en god Kristen og Jesu Ven."

I Kirkebønnen bad jeg dernæst under aandeløs Stilhed og med Navns Nævnelse for Fru Oberstinde Paludan-Müller og deres Børn, takkede Gud for det lysende Eksempel paa sandt dansk og kristent Mod, som deres tapre Fader havde givet, og at vi alle med dem maatte styrkes i en uforfærdet Tro paa Sejr og Oprejsning for Sandhed og Ret. 


\section{Konfrontation ved pinse-bryllup i Ullerup kirke}

Om Eftermiddagen havde jeg to Vielser. Den ene, som var aftalt Kl. 16.30, skulde nødvendigvis netop finde Sted Pinsedag, for at Brudgommens Bror - begge mine gamle Konfirmander - kunde være med til Brylluppet. Han var nemlig SS-Frivillig paa Orlov og skulde rejse Dagen efter. Da denne Vielse blev aftalt under dette Hensyn, betingede jeg mig, at SS-Manden skulde møde i civil i Kirken. Dette var jeg berettiget til, da kirkelige Handlinger efter Loven ikke kan forlanges udført paa en første Helligdag paa de store Højtider (hvad jeg unægtelig først huskede bagefter). Familien viste sig at være mere nazistisk end jeg anede, saa Muligheden ikke er udelukket, at man tilsigtede en Provokation. Da Klokken var 16.30 kom Brudens Søster ind i Præsterummet og bad, om at vi ikke kunde vente lidt endnu, da der skulde komme nogle flere Deltagere. Jeg indvilgede naturligvis, idet jeg troede, det maatte være Brudefolkene vi skulde vente paa. Lidt efter trak jeg Gardinet til side for at kunne skønne, hvornaar vi maatte begynde. Men derefter kom ingen flere eller andre end - Soldaten i den tyske Nazi-Uniform! Jeg gik da ud for at foreholde hans Fader dette Brud paa Aftalen. Til min Overraskelse saa jeg, at Brudeparret allerede sad for Alterskranken, og da Orgelet samtidig spillede, faldt Ordskiftet lidt kort. Paa min Henstilling til Faderen om at foranledige SS-Manden ud af Kirken, svarede han i stor Ophidselse »nej«.

Jeg var under det stadig friske Indtryk af Begivenhederne i Graasten ikke til sinde at ville taale ogsaa denne overlegne Haan af det, som var dansk og ret og tilbød derfor, at jeg ville gaa. Derpaa sprang Faderen op og forsvandt med Soldaten i ildevarslende Vrede ud af Kirken.

Jeg gennemførte derpaa Vielsen, som om intet var hændt, idet jeg talte ud fra det Ord, som Brudgommen havde faaet paa sin Konfirmationsdag: "Al god Gave er ovenfra og kommer ned fra Lysenes Fader." Som Eksempel paa de gode Gaver, Gud giver, nævnte jeg fra Luthers Forklaring til Fadervor: Dagligt Brød, Hus og Hjem, en god Ægtefælle og gode Børn, god og trofast Øvrighed og Styrelse i Landet, Fred, gode Venner og trofaste Naboer. Man maatte ogsaa som rimeligt huske at takke Gud for hans Gaver og ikke lade sig friste til Utaknemmelighed, saafremt fjendtlige og troløse Folk med ildesindet og løgnagtig Propaganda skulde forsøge at lægge vort Fædreland og de gode Livsvilkaar, det byder os, for Had. Saaledes vil og bør vi vise 
os som Børn af Gud, Lysenes Fader der giver gode Gaver - ikke at forglemme Syndernes Forladelse.

Da jeg bagefter lykønskede Brudefolkene og de nærmeste af Familierne, viste en Søster til SS-Manden, som for ikke længe siden var bleven konfirmeret, en utrolig Frækhed. Med knejsende Nakke snærrede hun: "Pas De bare paa med Deres Lys!“ (Hentydning til Talen), hvorpaa hun demonstrativt gjorde omkring og gik hoverende ud af Kirken. Den ældste Søster var derimod meget venlig. Hun havde tidligere fortalt mig, hvor ked hun var af Broderens Landsforræderi, og hvor pinligt de følte det med hans raa og brovtende Optræden, naar han var hjemme paa Egnen. Men ak, sagde hun, nu er jo desværre de fleste af Familien gaaet over til det tyske Parti. Jeg sagde til hende, at jeg vilde tale med hendes Fader, da det havde overrasket mig, at han tilsyneladende var bleven saa fornærmet. Det havde jeg ikke ventet, da han jo selv havde siddet i min stue og udtalt sin Sorg og Forbitrelse over, at Peter var kommen i med Nazisterne og bleven ledet ind $i$ dette saa ung. Aah, ja, sagde hun, men Far er nu saa hidsig, han vil desværre vist ikke lade sig tale til Rette.

Da jeg kom hjem fra Kirken, ringede Telefonen, som ellers er lukket om Søndagen. Det var Biskoppen fra Haderslev! Saa langt var Begivenheden allerede rygtedes, skønt der ikke var gaaet halvanden Time, siden Vielsen begyndte. Hvad der var foregaaet i den korte Tid, var følgende: Faderen og Soldaten var taget hjem til Blans. Overfor Naboen, Gdr. Andr. Madsen, havde de raset og truet med det værste. Denne havde ringet til Provsten om, hvad der kunde gøres for at redde Præsten. Provsten havde saa sat sig i telefonisk Forbindelse med Biskop Noack, som nu udbad sig en Forklaring om, hvad der var sket. Da jeg havde givet ham den i Overensstemmelse med foranstaaende, udtalte han, at der under de raadende Forhold ikke var andet at gøre end at tage ned og bede Familien om Undskyldning. Jeg sagde, at jeg havde sendt Bud, at jeg vilde tale med Faderen en af de nærmeste Dage. Biskoppen mente, det helst maatte ske straks.

Det blev en temmelig farefuld Færd. Da jeg nærmede mig Huset hvor Bryllupsselskabet var samlet, stod nogle Piger med den truende Dame fra Kirken paa Trappen og raabte til Herrerne: "Smid da den Karl ud af Gaarden«. Brudgommen kom mig ligbleg imøde og bad mig forlade Stedet, da de efter dette ikke vilde have mere med mig at gøre. Jeg forlangte imidlertid først at tale med Faderen, som derefter kom frem. Han var dog stadig helt ubehersket og erklærede raa- 
Ullerup kirke set fra vest. Foto $i$ Institut for Sønderjysk Lokalhistorie.

bende, at nu nyttede ikke mere nogen Snak eller Undskyldning, det skete var allerede forlængst ude over Sognets Grænser. Dertil svor han, at han eller hans Børn ikke mere skulde sætte deres Ben i Kirken (hvilket i Parentes bemærket ikke vilde betyde nogen synderlig Forandring i deres hidtidige Praksis). Soldaten bandede truende, at han var lige saa god Dansker som jeg. Og var det ikke min Hensigt at bede om Undskyldning, endsige da erklære, at jeg beklagede min Optræden, saa naaede jeg det heller ikke. Brudens Søster, der havde bedt mig vente i Kirken, kom nemlig farende med min Cykel fra Lademuren og erklærede, at nu skulde Snakken have Ende og jeg ud af Gaarden. Med den Bemærkning, at de forhaabentlig med Tiden vilde se lidt mindre ophidsede paa Sagen, forlod jeg saa med tilsyne- 
ladende uforrettet Sag dette sydende Infernum, idet jeg undrede mig over, at en saadan Udvikling var mulig. Jeg havde altid haft et godt Forhold til begge Familier, for Soldatens Far havde jeg konfirmeret en hel Række Børn, skaffet ham Penge fra "Den Sønderjydske Fond", begravet hans Hustru, aarligt været inde med Penge af Juleuddelingen o.s.v. og ment, at vi var fine Venner og nationalt Meningsfæller.

\section{»Under jorden«}

Næste Dag, 2. Pinsedag, fortalte Soldatens Paarørende til Folk (paa Ballegaard), at de havde meldt mig til Tyskerne. Vore Venner i Blans raadslog i Løbet af Formiddagen, og om Middagen efter Kirken kom Frk. S. Madsen og meddelte os, at der var Fare og jeg straks maatte væk. Det blev en brat Afslutning igen paa Tjenesten, som jeg lige havde paabegyndt efter Syge-Orloven. Efter en hurtig Afsked med Hjemmet - den mindste af Børnene laa paa Sofaen i min Stue og sov cyklede jeg ned til Biskop Noack, hvor jeg fik en hjertelig Modtagelse og Tilbud om foreløbigt Ophold. Til min udførlige Rapport bemærkede Biskoppen smilende: "Ja, jeg kan ærlig talt godt forstaa Dem.«

Jeg boede nogle Dage hos Familie paa Haderslev Egnen og fik daglig Underretning fra Biskoppen om, hvorvidt der fremkom noget om Affæren i det tyske Blad. Det skete ikke, hvad jeg opfattede som foruroligende. Det samme gjorde andre. Da jeg en Aften spiste Middag hos Børsen Hansen og Frue, som stammer her fra Sognet, erklærede han, at efter hans Bedømmelse stod min Sag ikke godt, jeg maatte under ingen Omstændigheder vende hjem igen, men skulde til Sjælland og evt. til Sverrig. Han ringede til Biskoppen, som paa hans Forespørgsel erklærede, at han ordnede alt vedrørende Embedets Betjening, og at min Hustru vilde faa Lønningen udbetalt ubeskaaret under mit Fravær.

Inden jeg rejste videre, mødte jeg den første Hjælp fra Politiets Side, idet en Kriminalbetjent $i$ Vojens (Mehlsen), udleverede mig et Legitimationskort til Udfyldning efter Behag, og som han derefter vilde forsyne med Politiets Stempel.

Paa Sjælland kom jeg hurtigt i Kontakt med de »illegale« Kredse og mødte alle Vegne en uforglemmelig Hjælpsomhed gennem det følgende Aar.

Efter nogle Dage i København ankom jeg til min Søster og Svoger, Bang-Møller i Allerslev Præstegaard den 14. Juni 1944, hvor allerede 
en Ritmesterfrue (Astrid Scholten), holdtes skjult. Men allerede Dagen efter maatte jeg bort derfra, da der paa min Kones Vegne blev ringet fra Graasten, at jeg ikke maatte være hos Familien, da Gestapo havde været to Gange efter mig her i Præstegaarden.

I Brev ad Omveje fik jeg nærmere Besked om, hvad der var sket. Samme Dag, den 14. Juni ankom en Bil til Præstegaarden med fire Personer, hvoraf de to talte Dansk, den tredie Sønderjydsk og en Tysk. Under Foregivende af at skulle have Oplysninger fra Kirkebogen, spurgte de efter Præsten, som altsaa var saa heldig ikke at være hjemme. Paa min Hustrus Tilbud, at hun kunde ordne det og evt. udstede Attesten for dem, erklærede de, at der ogsaa var mere, saa de maatte tale med Præsten om, hvorfor de vilde komme igen. Mod Aften vendte de saa tilbage og forsøgte først i Haven at indsmigre sig hos en af Drengene for at faa ham til at sige, hvor Far var henne. Det vidste han ikke. De forlangte da Adressen hos min Hustru, som svarede, at hun ikke vidste, hvor jeg var. Hun spurgte om det var Tildragelsen $i$ Kirken Pinsedag, de interesserede sig for, hvad de bekræftede, idet de spurgte, om hun ikke syntes, det var mærkeligt at en Kone ikke vidste, hvor hendes Mand var henne. Min Kone svarede: „De kommer altsaa fra Gestapo, synes De da ikke ogsaa, at det er nogle mærkelige Tider vi lever i? « De forsvandt derefter med uforrettet Sag og kom ikke oftere.

I Organet Der S.K. Mann, Blatt der Sturm-Kolonnen Nordschleswig, Nr. 3 1944, læstes efter dette et svulstigt Digt af en Max Bökinghardt, som indeholdt en rasende Trusel. Overskriften lød: »Wir warnen Warncke! og der stod bl.a.:

„Herr Pastor Warncke, Pfarrherr der Gemeinde

Von Ulderup im schönen Sundewitt

Erklärt zum Beispiel jedem sich zum Feinde,

Der an der Ostfront gegen Rusland stritt,

Leicht sind in ihm erweckt des zornes Mächte,

Wo andre Liebe meinen sät er Hass.

Jedoch was er sich jüngst zu tun erfrechte,

Das übersteigt selbst sein gewohntes Mass.

Was uns betrifft, das mag er gerne wissen, Wir wïrden uns zu jeder Zeit bemühn, Ihm den Talar, und wenn die Nähte rissen, Mit Nachdruck über seinen Kopf zu ziehn.« 
I tjeneste igen, maj 1945

Uforglemmelig blev Hjemkomsten, da jeg paa Cykle naaede hjem fra Sjælland Mandag den 7. Maj 1945 efter at have gjort Ophold hos Biskop Noack i Haderslev for at melde mig til Tjeneste igen. Den begyndte med, at jeg holdt Takkegudstjeneste for Freden og Sejren, Kristi Himmelfartsdag, Torsdag den 10. Maj.

Min Hjemkomst var hurtigt rygtedes, og Frihedskæmperne meddelte mig telefonisk, at de havde planlagt i sluttet Trop at afhente mig og følge mig op til Kirken, men de var bleven forhindrede ved at blive udkommanderede til Tjeneste i Sønderborg samme Dags Morgen Kl. 6. Skønt Kirken om Søndagen havde været stærkt besøgt, som Tilfældet var de fleste Steder i Landet i spontan Glædesytring, var Kirken den Dag igen tæet fyldt. Da jeg gik op ad Kirkegulvet, rejste hele Menigheden sig til Velkommen, hvad mange Haandtryk bagefter bekræftede.

Det blev en meget festlig Gudstjeneste. Vi sang: "Den signede Dag med Fryd vi ser" - "Lover den Herre - "Forgæves er vor Kraft og Kunst« - "Vaj nu Korsets Flag« og »Nu takker alle Gud«.

Til Lektie fra Alteret læste jeg Sl. 21: »Herre, Kongen glæder sig i din Kraft, og hvor saare fryder Han sig ved din Frelse", o.s.v. hele Salmen, samt Sl. 9, 8-13. Efter Evangeliet paa Prædikestolen oplæste jeg det i Anledning af Krigens Slutning udsendte Hyrdebrev fra Biskopperne. Jeg prædikede derefter over Dagens Tekst med Anvendelse af Daniels Bog Kap. 7 om »den gamle af Dage« og "Menneskesønnen i Himlens Skyer«, Aabenbaringsbogen Kap. 18, og Grundtvigs Sang »Fædreneland ved den bølgende Strand «. Følgende Hovedtanker:

Vi ser i disse lykkelige Dage Dannebrog hæve sig frit, befriet i Solskinnet under Himlens Blaa. Paa Kristi Himmelfartsdag saa en lille Skare Mænd Jesus, Livets og Dødens Herre fra Gravenes Land, Syndens og Sorgens Hjem hæve sig mod Himlens Skyer for at tage Sæde ved "Kraftens højre Haand«. Da Han selv var Livet og Sandheden, betød dette en evig Garanti for Sandhedens og Rettens Sejr til Livets Fremgang. Det var ogsaa det Daniel og Johannes saa i deres profetiske Syner. Sandhedens og Rettens Verden hæver sig sejrrigt op af Undertrykkelsens Mørke. Sammen med de andre gaar ogsaa vort Folk nu atter ind til Livet i Frihedens skønne Solskinsdage. Herren bebrejdede Apostlene deres Vantro overfor Vidnesbyrdet om Opstandelsen. Alt- 
saa maa heller ikke vi være vantro, og naar vi nu skal være med til at opbygge en ny og bedre Fremtid for vort Folk og Verden, saa lad os gøre det $\mathrm{i}$ en frejdig Fortrøstning til Gud og de frelseshistoriske Kendsgerninger, som vi bekender os til i den kristne Tro.

Ullerup Præstegaard i Juni 1947. Carl Warncke.

\section{Efterskrift: Warncke og Folkekirken}

Pastor Carl Warnckes stridbar- og principfasthed under Besættelsen var hverken typisk for præstestanden eller den danske Folkekirke som sådan. Warnckes position har sikkert været rundet af såvel hans karakteregenskaber som hans nationale og kirkelige orientering. Det sidste var ikke uvæsentligt for den enkelte præsts opfattelse af besættelsen og hans ageren $i$ forhold til denne. Indre Mission, som sognepræsten i Ullerup var rundet af, så den tyske besættelse af Danmark som straffen for den omsiggribende kulturradikalisme og materialisme. Den anden kirkelige hovedretning, grundtvigianismen, afviste, at besættelsen så at sige var Gud-villet. Modsat missionsfolkene var man indstillet på at acceptere 9. april-ordningen med dens tyske (illusoriske) løfter om dansk selvstændighed og neutralitet. Ganske som Indre Mission mente de grundtvigske, at landets ulykke måtte medføre befolkningens ansvarliggørelse, men hvor Indre Mission, i hvert fald til en begyndelse, mente, at den ydmygende nationale situation tilsagde tavs selvransagelse, søgte grundtvigianerne tilbage $i$ folkets historie, og Grundtvig var naturligvis den store inspiration. Folkets beståen afhang ikke af ydre forhold, men af folkets forhold til den åndelige arv og troen på, at Gud havde givet danskerne landet og ville bevare det, så længe danskerne var tro mod deres opgave - en national opgave som grundtvigianerne så som Gud-givet. Denne fokusering på sammenhængen mellem det indre og det ydre gjorde det altovervejende flertal af grundtvigianerne til faste støtter for den danske samarbejds- og forhandlingspolitik i forhold til besættelsesmagten - uden at man dog af den grund var ukritiske over for samlingsregeringens enkeltdispositioner eller -personer. Holdningen var, at forhandlingspolitikken netop gav danskerne den frihed $i$ de indre, åndelige forhold, som for de grundtvigske var de ydre forholds forudsætning. Hvis man som missionsfolkene vedblev med at fokusere på skyld og ansvar, ville det efter de grundtvigskes mening blot føre til indre opløsning. I stedet skulle man skabe en national samling over 
for besættelsesmagten. Alsangs-bølgen i 1940 og skabelsen af Dansk Ungdomssamvirke var direkte resultater af den grundtvigske opfattelse. Indre Mission vægrede sig derimod ved at tilslutte sig Dansk Ungdomssamvirke, bl.a. fordi det efter missionsfolkenes mening forfulgte verdslige mål, hvor forholdet til Gud måtte være det centrale. Senere under Besættelsen blev Indre Mission langt mere tilbøjelig til at forholde sig til verdslige, politiske forhold.

Mindre kirkelige retninger som Kirkeligt Forbund og Barthianerne, som var inspireret af den svejtsiske teolog Karl Barth, var også skeptiske over for Ungdomssamvirket og i det hele taget samarbejds- og forhandlingspolitikken. At ligge underdrejet, indtil stormen var ovre, hjalp efter deres mening intet, for ingen ydre garantier for Danmarks uafhængighed hjalp, hvis ikke folket fandt den indre integritet og den åndelige og personlige suverænitet.

Især Tidehverv kunne ikke acceptere 9. april-ordningen og et initiativ som Ungdomssamvirket. Tendenserne til at indrette sig efter de nye tider, dvs. den tyske besættelse, spærrede efter Tidehvervs opfattelse blot for erkendelsen af nederlaget. $\mathrm{Og}$ når man i Tidehverv ikke havde tiltro til Ungdomssamvirket, skyldtes det dets mål om massepåvirkning, hvor der ifølge Tidehverv var behov for personlig selvstændighed. At værne friheden var ganske rigtigt en vigtig opgave, men det var noget, man skulle påtage sig som menneske uden at tage Gud til indtægt.

Som institution fandt Folkekirken hurtigt sin plads i besættelsessystemet. Man støttede kongens og regeringens parole om »ro og orden«. Tidens alvor tilsagde ikke noget oprør, men det var karakteristisk, at i det omfang man kan tale om fløje i det kirkelige liv, var reservationerne overfor 9 . april-ordningen med den efterfølgende samarbejds- og forhandlingspolitik størst på højrefløjen, som også omfattede en del højregrundtvigianere.

I takt med regeringens indrømmelser over for tyske krav blev de principielle uenigheder $\mathrm{i}$ det kirkelige landskab stadig mere udtalte, og to hovedstandpunkter udviklede sig: det ene hovedstandpunkt var, at ansvaret for den danske Folkekirke og regeringens og kongens vanskelige situation nødvendiggjorde, at man ikke tog stilling til aktuelle politiske ( $i$ bredeste forstand) spørgsmål i prædikerne. Teologisk støttede dette hovedsynspunkt sig til den opfattelse, at Guds ord var evigt aktuelt og ikke skulle indrette sig på særlige situationer. Det andet hovedsynspunkt var, at ansvaret over for etiske principper som 
ret og sandhed måtte have primat over for alle andre hensyn. Derfor måtte kirken sige fra, når sandhed og ret blev knægtet. Vel var kirken forpligtet til lydighed over for den rette øvrighed, men øvrigheden havde selv undsagt loyalitetsforholdet, når den tillod krænkelser af sandhed og ret. Kirken kunne ikke fortsætte, som om intet var hændt, men måtte tværtom protestere og forkynde Ordet ind i den aktuelle situation. Groft betegnet var det første hovedsynspunkt det grundtvigske, og det andet det ikke-grundtvigske. Pastor Warnckes pinseprædiken 1944 er et eksempel på, at Ordet blev forkyndt ind i en aktuel situation, og at ret og sandhed blev fremhævet som havende primat over alle andre hensyn.

De to hovedsynspunkter udkrystaliseredes tydeligt fra omkring 1942. Især skreddet $i$ jurisdiktionen, dvs. den stigende tyske indblanding $\mathrm{i}$ retsforfølgelsen af danske borgere, stillingen til den såkaldte »kirkekamp« i Norge, racespørgsmålet og den begyndende »båndlæggelse af evangeliets frihed « i form af diverse cirkulærer fra Udenrigsministeriet og Kirkeministeriet satte tingene på spidsen og skilte vandene. Nok kunne Kirkeministeriet principielt ikke blande sig i forkyndelsen, ikke desto mindre holdt ministeriet præsterne i særdeles stramme tøjler. Efter maj 1945 hed det sig, at dette skete på tysk forlangende, men der var fra Kirkeministeriets side $i$ høj grad tale om forebyggende selvcensur- og -justits.

På den kirkelige højrefløj og i de økumeniske kredse voksede utilfredsheden med tingenes tilstand i løbet af 1943, og fra disse kredse blev der lagt et betydeligt pres på biskopperne. Disse manede dog til besindighed, idet man henviste til, at man var tjenestemænd og ansvarlige over for centraladministrationen og over for kongens og den afgåede regerings bud.

Med overgrebet på de danske jøder i oktober 1943 øgedes presset på biskopperne i en grad, så en kirkelig stillingtagen i den konkrete situation var uomgængelig. Det resulterede i »jøde-hyrdebrevet", som Warncke også omtaler i sin beretning, og ganske som i Warnckes beretning er dette hyrdebrev blevet fremholdt som et udtryk for en samlet og enig stillingtagen fra Folkekirken. Sandheden er imidlertid, at der ikke stod et enigt bispekollegium bag hyrdebrevet, eller i hvert fald dets formulering. Havde Kobenhavns biskop Fuglsang-Damgaard ikke skåret igennem og taget et selvstændigt initiativ, tyder alt på, at hyrdebrevet var blevet formuleret anderledes diplomatisk. Senere hyrdebreve, som biskopperne blev tvunget til at udsende af akti- 
vistiske kredse blandt præsterne, blev under diskussionerne i bispekollegiet så tilfilede, at det krævede nærlæsning overhovedet at få budskabet frem. F.eks. det hyrdebrev, som blev udsendt i februar 1944 efter drabet på Kaj Munk - en tildragelse, som gjorde et stærkt indtryk i gejstlige kredse, således også på Warncke. Selv om »Kaj Munk hyrdebevet «, som i øvrigt efter tilfilingen ikke explicit nævnte Kaj Munk, blev svækket markant, synes det ikke desto mindre at have været skelsættende, for mens jøde-hyrdebrevet var en del af en større protest fra de bærende samfundsinstitutioner, var Kaj Munk-hyrdebrevet udtryk for, at kirkens ledelse i denne sag fandt, at politiske hensyn måtte vige. Drabet var en så stor rystelse, at kirken valgte at lægge afstand til øvrighedens påbud om tavshed i sagen. Biskopperne nægtede endda at videreformidle det ministerielle påbud til provster og menige præster. Også fordi biskopperne indså, at det ville gøre deres egen stilling over for præsterne helt uholdbar.

Ét hyrdebrev udsendte biskopperne uden pres fra neden og uden forudgående sværdslag om formuleringen, nemlig det, der blev udsendt $\mathrm{i}$ forbindelse med Danmarks befrielse!

Biskopperne var som kollegium system-loyale, og det samme var hovedparten af de menige præster. ${ }^{9}$

Carl Warncke har sandsynligvis, i hvert fald til en begyndelse, også grundlæggende støttet den danske regerings samarbejds- og forhandlingspolitik over for den tyske besættelsesmagt. Et væsentligt element i legitimeringen af denne politiske kurs var nemlig den nationale samling: man måtte samles om alt dansk og undgå at blive rendt over ende af den tyske kultur. En sådan parole fandt ikke mindst klangbund i Sønderjylland, hvor erindringen om tiden fra 1864 til 1920 endnu var frisk, og hvor hjemmetyske krav om en grænserevision skabte frygt, men også beslutsomhed. Herom vidner den massive opbakning bag Danske Samfund i Sønderjylland - en masseorganisation, som også grundlæggende lå i forlængelse af regeringens politik, men hvor mange medlemmer ikke desto mindre opfattede sig som del af en bred "modstandsfront", ganske som provst Jens Holdt fra Brede karakteriserer det i sin dagbog fra Besættelsen. ${ }^{10}$ Især i en sønderjysk sammenhæng var denne "modstandsfront “ at forstå som rettet mod det tyske mindretal og de danske nazister, hvilket på ingen måde kolliderede med den danske regerings politik og en meget bred national konsensus om at isolere nazister her til lands. For pastor Carl Warncke var der imidlertid tydeligvis en grænse $\mathrm{i}$ forhold til 
øvrighedens bud: en præst skulle frem for alt være sandhedsvidne, og kom man til at lide for sandhedens skyld, var det situationens krav.

NOTER

1. Den Nordslesvigske Kirke. Landsdelens Kirkeliv og Sognekirker. Skrevet af sønderjyske Præster. Under Redaktion af Pastor H. Hejselbjerg Paulsen. Haderslev 1948, II Del, s. 353.

2. Dansk Præste- og Sognehistorie. Redigeret og udgivet af Anders Pontoppidan Thyssen. Århus 1977-91. Bd. X. Haderslev Stift, Ullerup sogn (af Torben F. Jergensen), s. 602-607.

3. Sammenlign iøvrigt med Henrik Skov Kristensen (udg.): "Jens Holdt: Brede sogn under besættelsen « $i$ : Sønderjyske Arboger 1995, s. 363-413. Her ses en parallel "gejstlig" beskrivelse af de nationale modsætninger $i$ Brede Sogn af provst Jens Holdt.

4. De mange bomber i Ullerup sogn og ikke mindst på Nordals natten mellem den 18. og 19. august 1942 faldt $i$ forbindelse med et fejlslagent britisk luftangreb på værftet $i$ Flensborg. Se Henrik Skov Kristensen, Claus Kofoed og Frank Weber: Vestallierede luftangreb $i$ Danmark under 2. Verdenskrig bd. I-II. Aarhus Universitetsforlag 1988 , s. 312-313. Eller mere udførligt i Henrik Skov Kristensen og Inge Adriansen Als og Sundeved 1940-45. Historisk Samfund for Als og Sundeved 1995, s. 38-44.

5. Pastor Martin Niemöller var leder af den tyske "bekendelseskirke«, som var i opposition til det nazistiske styre. Niemöller selv blev sat i koncentrationslejr på grund af sine anskuelser.

6. Den hjemmetyske, og i øvrigt også nazistiske, vrede mod provst Schülein i Løgumkloster skyldtes, at han havde nægtet at medvirke ved en mindehøjtidelighed i kirken for en falden frikorpsmand fra Ellum. Overfor det hjemmetyske krav om fjernelse af Schülein fra grænselandet reagerede præsterne i provstiet med en solidari- tetserklæring, som blev tilstillet Kirkeministeriet. Se herom i Henrik Skov Kristensen (udg.): "Jens Holdt: Brede sogn under besættelsen ", Sonderjyske Ärboger 1995, s. 382-383.

Lektor Viggo Rosent fra Statsskolen i Aabenraa var også tilknyttet den lokale handelsskole. Her havde han i forbindelse med undervisningen kommenteret et nazi-møde i Sportpalast i Berlin i 1938 med ordene: »Man skulle tro det var en flok gadedrenge«. I årene derefter forfulgtes Rosent af nazister $i$ det tyske mindretal, og i 1942 blev han korporligt afstraffet af SK-mænd. Se herom Aabenraa bys historie bd. 3, Aabenraa 1974, s. 194 og s. $227 \mathrm{f}$.

7. Ca. 250 fremtrædende samfundsborgere ud over landet blev taget som gidsler af tyskerne i forbindelse med den danske regerings tilbagetræeden $i$ august 1943 og den påfølgende tyske militære undtagelsestilstand. Godt 100 af dem blev overført til Horserødlejren, hvorfra de sidste blev løsladt $\mathbf{i}$ begyndelsen af november.

8. Pilgrim må have været besætningsmedlem på Lancaster JB 412, som under et togt mod Berlin styrtede ned ved Varnæes natten til den 29. januar 1944. To besætningsmedlemmer $T$. K. McCash og J.J. Martin sprang ud med faldskærm fra for lav højde og blev dræbt. De blev begravet på Aabenraa kirkegård den 2. februar 1944. Et tredje besætningsmedlem J.R. Tree blev fundet druknet ved Sønderborg i juni 1944. Han blev begravet i Aabenraa den 22 . juni. Fire besætningsmedlemmer, hvor Ronald Pilgrim må have været blandt, overlevede og blev taget til fange. Se herom i Anders Bjørnvad: Faldne Allierede Flyvere 1939-1945. Odense Universitetsforlag 1995, s. 163. 
9. Ridset af de kirkelige retningers positioner og kirken $\mathrm{i}$ det hele taget under Besættelsen baserer sig på Erik Thostrup Jacobsen: Som om intet var hændt - den danske folkekirke under besættelsen. Odense Universitetsforlag 1991 samt på Henrik Skov Kristensen: "Kirken under besættelsen " Historie 1996, s. 152-157 (anmeldelse af Tho- strup Jacobsens værk samt af Anders Bjørnvads På vej mod hjemstarnsret om den katolske kirke i Danmark under Besættelsen).

10. Henrik Skov Kristensen: "Jens Holdt: Brede sogn under besættelsen « Sønderjyske Arboger 1995, s. 373 og note 5 s. 409 . 